\title{
IMPLEMENTASI PERMEN ESDM NO. 17 TAHUN 2012 SEBAGAI SOLUSI ANTARA PENGUSAHAAN MINERAL DAN PERLINDUNGAN KAWASAN KARST DI INDONESIA
}

\author{
Aris Dwi Nugroho"), Tantan Hidayat", dan Muhammad Wachyudi Memed ${ }^{\text {l) }}$ \\ *E-mail:arisdwinugroho@ rocketmail.com \\ E-mail:arisdwinugroho@ rocketmail.com
Bidang Geologi Lingkungan, Pusat Airtanah dan Geologi Tata Lingkungan, Badan Geologi
}

\begin{abstract}
ABSTRAK
Semen adalah serbuk atau tepung yang terbuat dari kapur dan material lainnya yang dipakai untuk membuat beton, merekatkan batu bata ataupun membuat tembok (Kamus Besar Bahasa Indonesia, 2008). Semen merupakan suatu bahan yang bersifat hidrolis, yaitu bahan yang akan mengalami proses pengerasan pada pencampurannya dengan air ataupun larutan asam. Bahan baku pembuatan semen antara lain : clinker/terak semen sebanyak 70\% - 95\% (hasil olahan pembakaran batu kapur, pasir silika, pasir besi dan tanah liat), gypsum 5\% dan material tambahan lain (batu kapur, pozzolan, abu terbang dan lain- lain). Seiiring dengan peningkatan pembangunan insfrastruktur yang menjadi fokus Pemerintah saat ini, maka kebutuhan bahan baku bangunan khususnya semen mengalami peningkatan. Peningkatan kebutuhan ini membuat perusahaan semen meningkatkan produksi yang pada akhirnya juga akan mengurangi cadangan batugamping yang ada di alam. Sumber daya geologi terdiri atas sumber daya mineral, sumber daya energi, sumber daya air, dan bentang alam. Batugamping sebagai salah satu bahan baku dominan pembuatan semen merupakan sumber daya mineral dan bentang alam yang harus dilindungi. Kementerian Energi dan Sumber Daya Alam sejak tahun 2012 telah menerbitkan aturan terkait pemanfaatan dan perlindungan Kawasan Bentang Alam Karst (Permen ESDM N0. 17 Tahun 2012). Perlindungan terhadap Kawasan Bentang Alam Karst bertujuan untuk melindungi fungsinya sebagai pengatur alami tata air dan keunikan/nilai ilmiah dalam pengembangan ilmu pengetahuan. Sedangkan upaya pemanfaatan sebagai bahan galian maupun bahan baku industri diatur deliniasinya, sehingga tidak menganggu zona konservasi. Diharapkan dengan keluarnya Permen ESDM N0. 17 Tahun 2012 dapat menjadi solusi bagi pemanfaatan dan perlindungan Kawasan Bentang Alam Karst di Indonesia.
\end{abstract}

Kata kunci: Sumber daya geologi, Semen, Kawasan Bentang Alam Karst

\begin{abstract}
Cement is powder made from lime and other materials used to make concrete, glue bricks or make walls (KBBI, 2008). Cement is a material that is hydraulic in nature, that is, a material which will undergo a hardening process in its mixing with water or acid solution. The raw materials for making cement include: clinker I slag of cement as much as 70\% - 95\% (the results of the combustion of limestone, silica sand, iron sand and clay), 5\% gypsum and other additional materials (limestone, pozzolan, fly ash and etc). Along with the increase in infrastructure development which is the focus of the Government at this time, the need for building materials, especially cement, has increased. This increase in demand has made cement companies increase production, which in turn will also reduce the limestone reserves that exist in nature. Geological resources consist of mineral resources, energy resources, water resources, and landscapes. Limestone as one of the dominant raw materials for making cement is a mineral and landscape resource that must be protected.
\end{abstract}


The Ministry of Energy and Natural Resources since 2012 has issued regulations relating to the use and protection of Karst Landscape Areas (Permen ESDM No. 17 of 2012). Protection of the Karst Landscape Area aims to protect its function as a natural regulator of the water system and its unique I scientific value in the development of science. Meanwhile, the delineation of utilization efforts as minerals and industrial raw materials is regulated so that it does not disturb the conservation zone. Expected with the regulations (Permen ESDM No. 17 of 2012) can be a solution for the use and protection of the Karst Landscape in Indonesia.

Keywords: Geological resources, Cement, Karst Landscape Area

\section{A. PENDAHULUAN}

Indonesia adalah negara yang sangat kaya dengan sumber alam, baik sumber daya alam yang bisa diperbarui (renewable source) maupun sumber daya alam yang tidak bisa diperbarui (non renewable source). Sumber daya alam yang dapat diperbarui antara lain berupa : kayu, minyak sawit, hasil perkebunan, hasil pertanian, dan lain-lain. Sedangkan sumber daya alam yang tidak dapat diperbarui berupa : minyak bumi, gas bumi, batubara, mineral dan batuan. Kepulauan Nusantara yang merupakan tumbukan (subduksi) dari 3 lempeng menghasilkan banyak sekali mineral dan batuan. Salah satu batuan yang penyebarannya merata di semua pulau adalah batugamping. Batugamping adalah batuan yang tersusun atas mineral kalsium karbonat $\left(\mathrm{CaCO}_{3}\right)$ dan terbentuk secara alami di bawah permukaan laut akibat akumulasi cangkang, karang, alga, dan pecahanpecahan sisa organisme. Batu gamping dapat dibedakan menjadi 3 (tiga), yaitu : batugamping klastik, batugamping bioklastik, dan batugamping kristalin/terumbu. Batugamping berfungsi sebagai sumber mineral industri dan penjaga kestabilan sumber daya air.

Semen adalah serbuk atau tepung yang terbuat dari kapur $\left(\mathrm{CaCO}_{3}\right)$ dan material lainnya yang dipakai untuk membuat beton, merekatkan batu bata ataupun membuat tembok (Kamus Besar Bahasa Indonesia, 2008). Semen merupakan suatu bahan yang bersifat hidrolis, yaitu bahan yang akan mengalami proses pengerasan pada pencampurannya dengan air ataupun larutan asam. Bahan baku pembuatan semen antara lain : clinker/terak semen sebanyak 70\% - 95\% (hasil olahan pembakaran batu kapur, pasir silika, pasir besi dan tanah liat), gypsum 5\% dan material tambahan lain (batu kapur, pozzolan, abu terbang dan lain-lain).

Seiiring dengan peningkatan pembangunan insfrastruktur yang menjadi fokus Pemerintah saat ini, maka kebutuhan bahan baku bangunan khususnya semen mengalami peningkatan sebesar. Peningkatan kebutuhan ini membuat perusahaan semen meningkatkan produksi yang pada akhirnya juga akan mengurangi cadangan batugamping yang ada di alam. Di sisi lain batugamping adalah akuifer yang baik dalam menjaga kestabilan pasokan airtanah di alam. Didalam batugamping terdapat pori-pori dan rekahan yang mampu menyimpan dan meloloskan air hujan sehingga masuk menjadi cadangan airtanah dalam. Bahkan di beberapa tempat sungai bawah dijadikan sumber utama untuk mencukupi kebutuhan air masyarakat. Kementerian Energi dan Sumber Daya Mineral diberikan mandat untuk menyelaraskan kebutuhan industri semen dan perlindungan sumber daya air serta bentang alam karst. 


\section{B. MAKSUD DAN TUJUAN}

Peraturan Menteri Energi dan Sumber Daya Mineral Nomor 17 Tahun 2012 ini bermaksud untuk menyelaraskan kebutuhan batugamping untuk industri semen dengan perlindungan sumber daya air, sedangkan tujuannya adalah :

a. Melindungi Kawasan Bentang Alam Karst yang berfungsi sebagai pengatur alami tata air;

b. Melestarikan Kawasan Bentang Alam Karst yang memiliki keunikan dan nilai ilmiah sebagai objek penelitian dan penyelidikan bagi pengembangan ilmu pengetahuan;

c. Mengendalikan pemanfaatan Kawasan Bentang Alama Karst

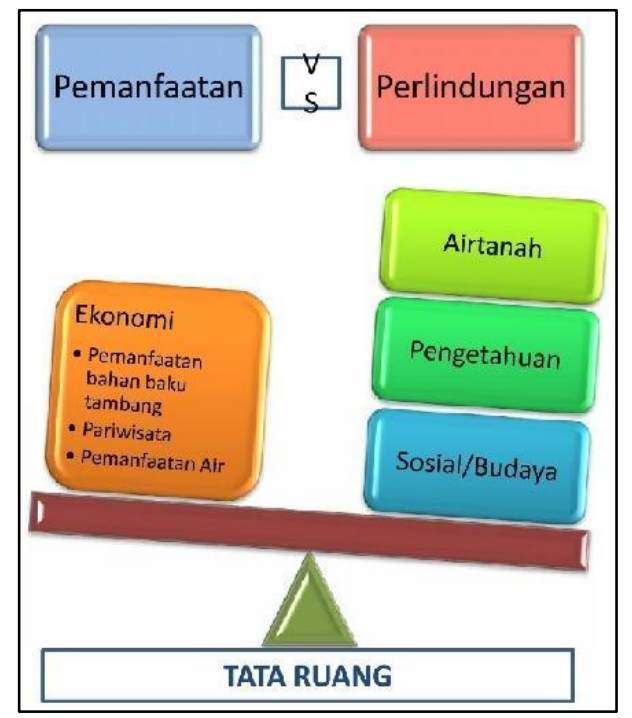

Gambar 1. Diagram Alir Pentingnya Perlindungan KBAK

\section{METODOLOGI PENELITIAN}

Penelitian ini dilakukan dengan pendekatan deskriptif melalui kajian pustaka, survei lapangan (groundcheck) dan wawancara. Kajian pustaka dilakukan dengan mempelajari Permen ESDM Nomor 17 tahun 2012 tentang Penetapan Kawasan Bentang Alama Karst dan dokumen pendukungnya.Survei lapangan dilakukan dengan mengamati lebih detail lokasi terpilih.Wawancara dilakukan pada masyarakat di sekitar objek guna mengetahui informasi perlindungan berkaitan dengan objek minatan. Selain itu wawancara juga dilakukan dengan pemerintah daerah setempat terkait dengan perencanaan dan pengembangan wilayah di Kabupaten Sorolangun, Provinsi Jambi.

\section{HASIL DAN PEMBAHASAN}

Proses penetapan Kawasan Bentang Alam Karst yang tertuang dalam Permen ESDM Nomor 17 Tahun 2012 dapat dipahami seperti diagram alir pada Gambar 2. Dalam makalah ini akan dipaparkan proses penetapan Kawasan Bantang Alam Karst Kabupaten Sorolangun, Provinsi Jambi sebagai contoh kasus dan diakhir pembahasan diberikan deliniasi seluruh Kawasan Bentang Alam Karst yang sudah ditetapkan oleh Menteri Energi dan Sumber Daya Mineral. 


\section{D.1. Identifikasi Potensi Karst}

Istilah karst (Slovenia: kras) berarti lahan gersang berbatu. Diadopsi untuk istilah bentuk lahan hasil proses pelarutan (walaupun tidak ada kaitan dengan batugamping dan pelarutan). Menurut Ford \& Williams (1989), karst adalah medan dengan kondisi hidrologi yang khas sebagai akibat dari batuan yg mudah larut dan mempunyai porositas sekunder (kekar dan sesar intensif) yang berkembang baik. Sedangkan menurut Permen ESDM Nomor 17 tahun 2012, Karst adalah bentang alam yang terbentuk akibat pelarutan air pada batugamping dan/atau dolomit. Karst dicirikan oleh adanya cekungan tertutup, langka/tidak adanya sungai permukaan, dan adanya gua dari sistem drainase bawah tanah.

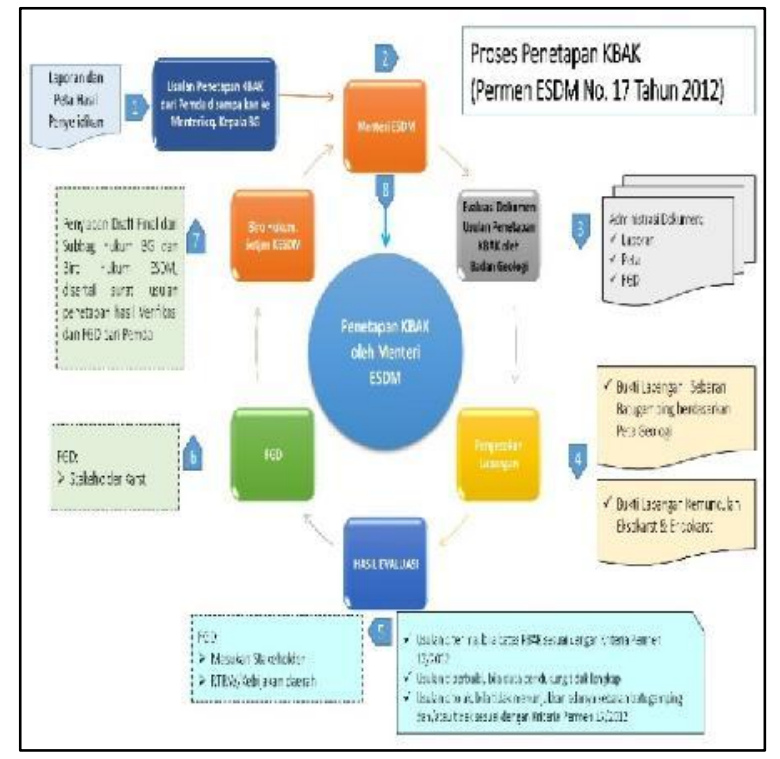

Gambar 2. Proses Penetapan KBAK

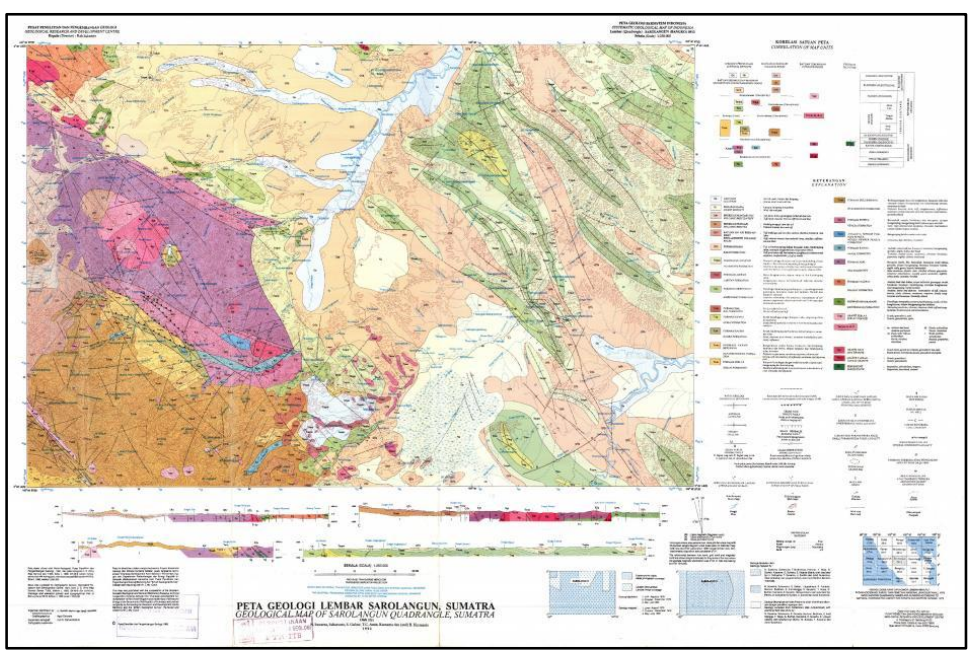

Gambar 3. Peta Geologi Lembar Sorolangun, Sumatra (PPPG, Badan Geologi, 1992)

Kawasan Bentang Alam Karst adalah Karst yang menunjukkan bentuk eksokarst dan endokarst tertentu. Penyelidikan pendahuluan sudah dilakukan oleh Tim dari Pusat Penelitian dan Pengembangan Geologi tahun 1992 yang beranggotakan : N. Suwarna, Suharsono, S. Gafoer, T.C. Amin, Kusnama dan B. Hermanto dengan hasil Peta Geologi Lembar Sarolangun, Sumatra skala $1: 250.000$. 
Dalam peta geologi ini terdapat 2 formasi dan 1 anggota formasi yang mengandung batugamping, antara lain :

a. Formasi Peneta $(K J p)$ : tersusun oleh batusabak, serpih, batulanau dan batupasir, sisipan batugamping mengandung fosil Clodocoropsis mirabilis.

b. Anggota Mersip Formasi Peneta $(\mathrm{KJpm})$ : tersusun oleh batugamping kristalin berwarna kelabu muda- tua.

c. Formasi Rawas (KJr) : Turbidit, wacke kerikilan, batupasir, batulanau, batugamping greywacke, argilit, diabas dan basal.

Khusus peta geologi Kabupaten Sorolangun dapat diperoleh dengan menggunakan aplikasi ArcGIS 10.5 menggunakan data peta dasar dari Kementerian Energi dan Sumber Daya Mineral, KSP 2019.

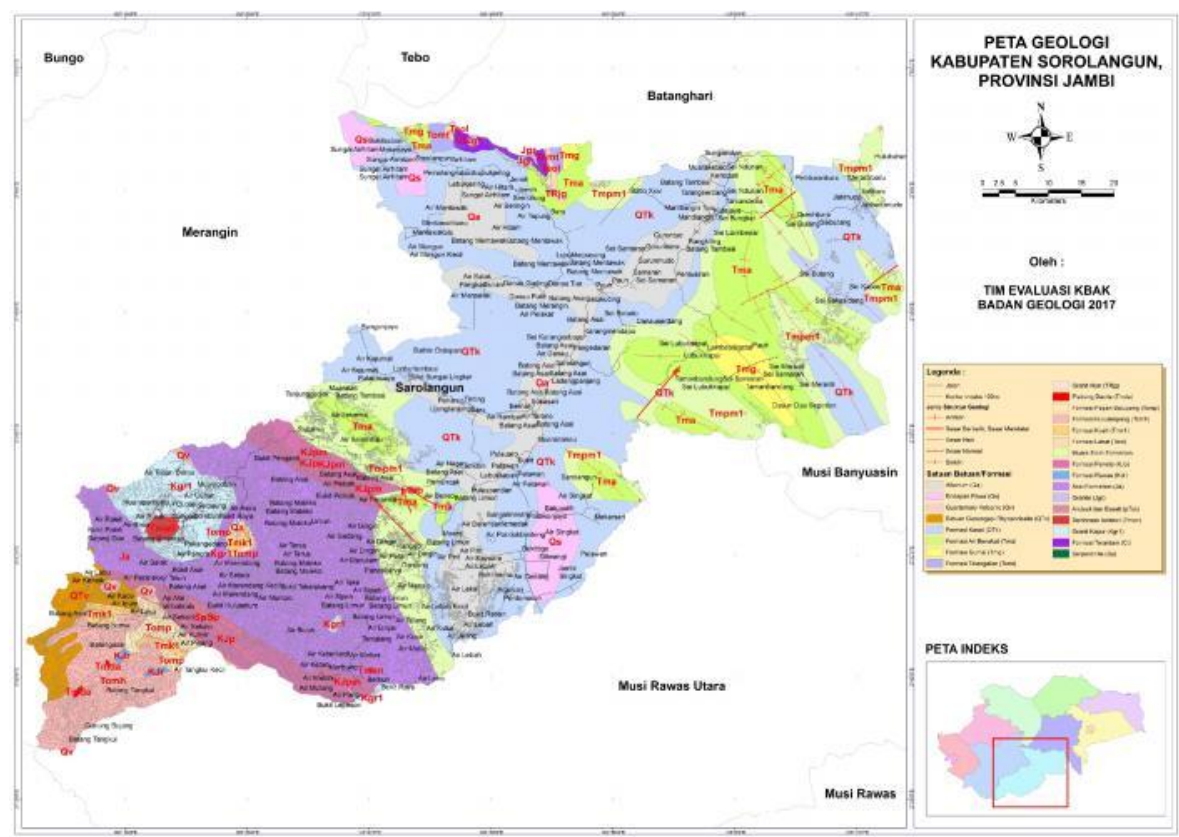

Gambar 4. Peta Geologi Kabupaten Sorolangun

\section{D.2. Pengusulan oleh Pemerintah Daerah}

Proses pengusulan dari Pemerintah Daerah diawali dengan Surat Gubernur Jambi Nomor : S3301/DESDM-3/XI/2017 tertanggal 3 November 2017, perihal Usulan Kawasan Bentang Alam Karst Provinsi Jambi.

\section{D.3. Verifikasi oleh Badan Geologi}

Berdasarkan surat Gubernur Jambi diatas, maka Badan Geologi Kementerian Energi dan Sumber Daya Mineral melalui Pusat Airtanah dan Geologi Tata Lingkungan bidang Geologi Lingkungan membentuk tim verifikasi kawasan bentang alam karst yang bertugas melakukan evaluasi dokumen usulan penetapan kawasan bentang alam karst dan penyelidikan lapangan dengan alur pekerjaan sebagai berikut: 


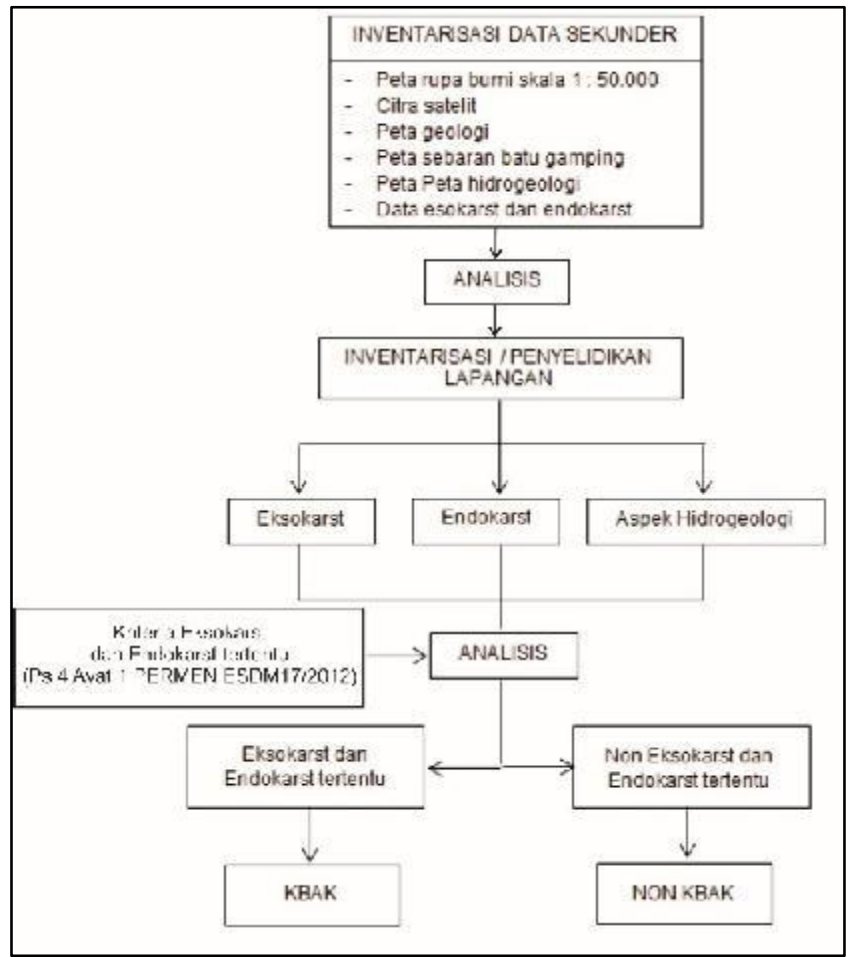

Gambar 5. Bagan Alir Penyelidikan KBAK

Pengamatan yang dilakukan dilapangan meliputi :

a. Pemetaan sebaran eksokarst yang meliputi :

- Mata air yang muncul pada batugamping yang menjadi sumber utama kebutuhan penduduk.

- Bukit karst berbentuk kerucut (conical), setengah bola (sinusoidal), dan menara (tower)

- Dolina, uvala, polje yang merupakan cekungan tertutup (multi basinal)

- Luweng dan ponor

- Telaga

b. Pemetaan sebaran endokarst yang meliputi :

- Sungai bawah tanah

- Speleotem (gua, ormanen-ornamen stalaktit, stalakmit, dll)

Pada pemetaan sebaran endokarst, baik untuk sungai bawah tanah maupun speleotem cukup dilakukan dengan memplotkan lokasi mulut gua yang menunjukkan adanya kedua obyek tersebut.

c. Pengamatan aspek hidrogeologi berkaitan dengan daerah imbuhan dan lepasan air tanah, batuan pengalir dan penyimpan air tanah (akuifer), keberadaan sungai bawah tanah, dan pemunculan mata air.

d. Tracking aliran sungai bawah tanah dengan menggunakan uranine atau sodium fluoiscein $\left(\mathrm{C}_{2} \mathrm{OH}_{10} \mathrm{O}_{5} \mathrm{Na}_{2}\right)$, bila diperlukan.

e. Pengambilan contoh air, meliputi air dari sungai, mata air, sungai bawah tanah, dan sumur gali yang diduga berkaitan dengan karst.

f. Pemotretan obyek-obyek terkait karst di lapangan.

Bentuk eksokarst dan endokarst tertentu sebagaimana dimaksud pada pasal 4 ayat (1) Permen ESDM No.17/2012 tentang Penetapan KBAK harus mempunyai kriteria sebagai berikut : 
i. Memiliki fungsi ilmiah sebagai obyek penelitian dan penyelidikan bagi pengembangan ilmu pengetahuan;

ii. Memiliki fungsi sebagai daerah imbuhan air tanah yang mampu menjadi media meresapkan air permukaan ke dalam tanah;

iii. Memiliki fungsi sebagai media penyimpan air tanah secara permanen dalam bentuk akuifer;

iv. Memiliki mata air permanen;

v. Memiliki gua yang membentuk sungai atau jaringan sungai bawah tanah. Sedangkan Delineasi Kawasan Bentang Alam Karst didasarkan pada :

- Batas sebaran formasi batugamping

Sebaran batugamping di daerah Mersip, Meribung dan Napal Melintang Kecamatan Limun

Kabupaten Sarolangun merupakan batu gamping dari Anggota Mersip Formasi Peneta $(K J p m)$ yang berumur Kapur. Batugamping di daerah ini terdiri merupakan batugamping klastik berwarna kelabu muda hingga tua. Sebaran batugamping Anggota Mersip Formasi Peneta $(K J p)$ di daerah ini bentuknya memanjang berarah barat - timur mengikuti rangkaian perbukitan di daerah tersebut.

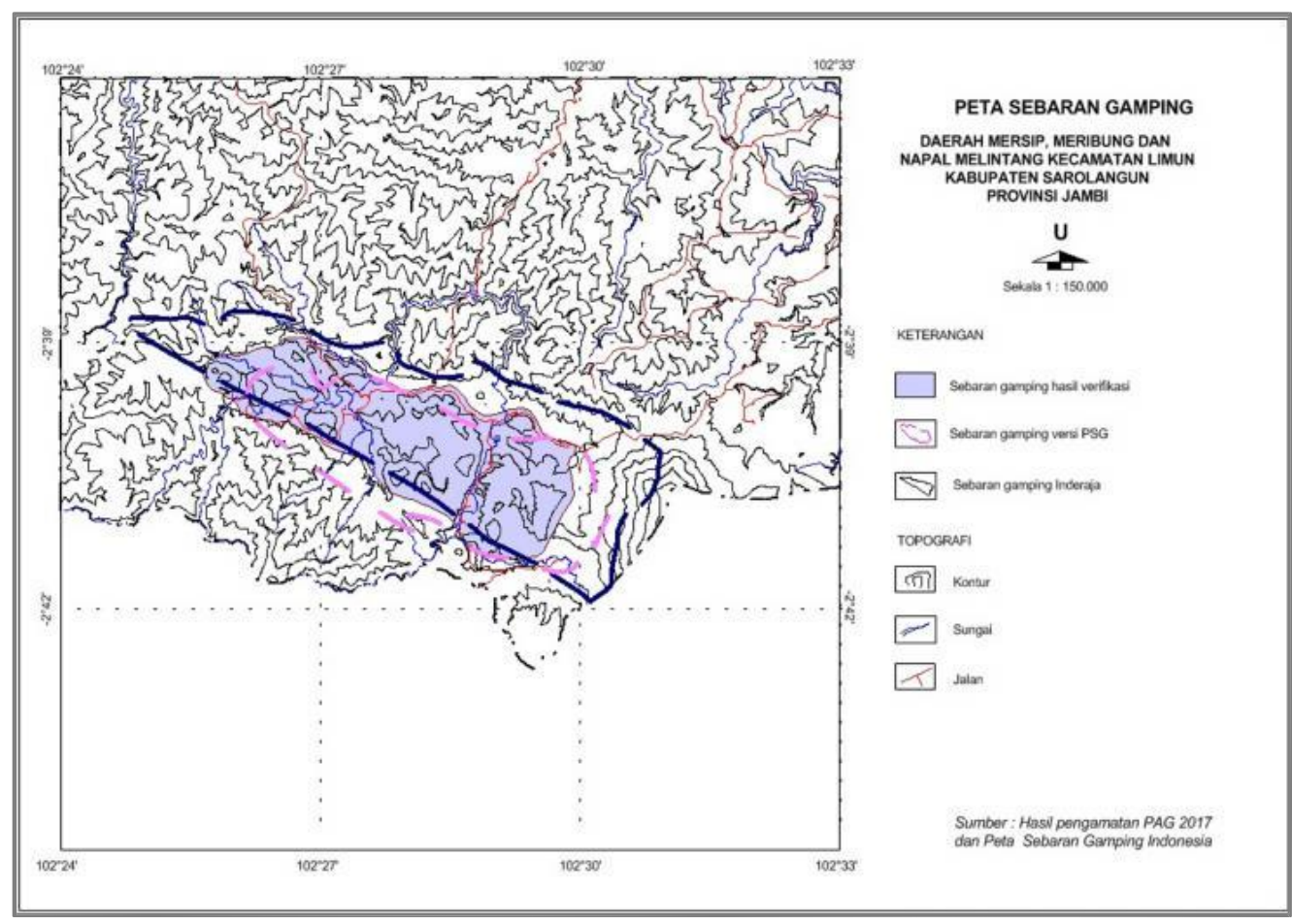

Gambar 6. Peta Sebaran Batugamping Daerah Mersip dan sekitarnya

- Sebaran eksokarst (bukit, dolina, uvala dan mata air)

Bukit-bukit pada kawasan ini dicirikan oleh bukit-bukit yang menonjol dan terpisah satu sama lain (scatter) yang sejajar arah Barat Laut-Tenggara (Gambar 6). Bukit-bukit tersebut diantaranya, Bukit Bulan, Bukit Calo Tengah dan Bukit Tembulun dengan ketinggian $200 \mathrm{~m}$ (lembah) sampai sekitar $390 \mathrm{~m}$. Di daerah penyelidikan terdapatnya sejumlah cekungan sebagai akibat depresi dengan bentuk dan ukuran yang bervariasi, cekungan tersebut digenangi air atau tanpa air dengan kedalaman dan jarak yang berbeda-beda salah satunya terdapat di daerah Napal melintang.

Mata air, keterdapatan mata air berada hampir pada semua daerah kaki lereng pegunungan karst Mersip, Meribung dan Napal Melintan di Kecamatan Limun, (Gambar 7). Mata air 
tersebut dimanfaatkan oleh penduduk setempat,debit mata air kecil berkisar antara 0,2 1/det hingga $1,8 \mathrm{l} / \mathrm{det}$.

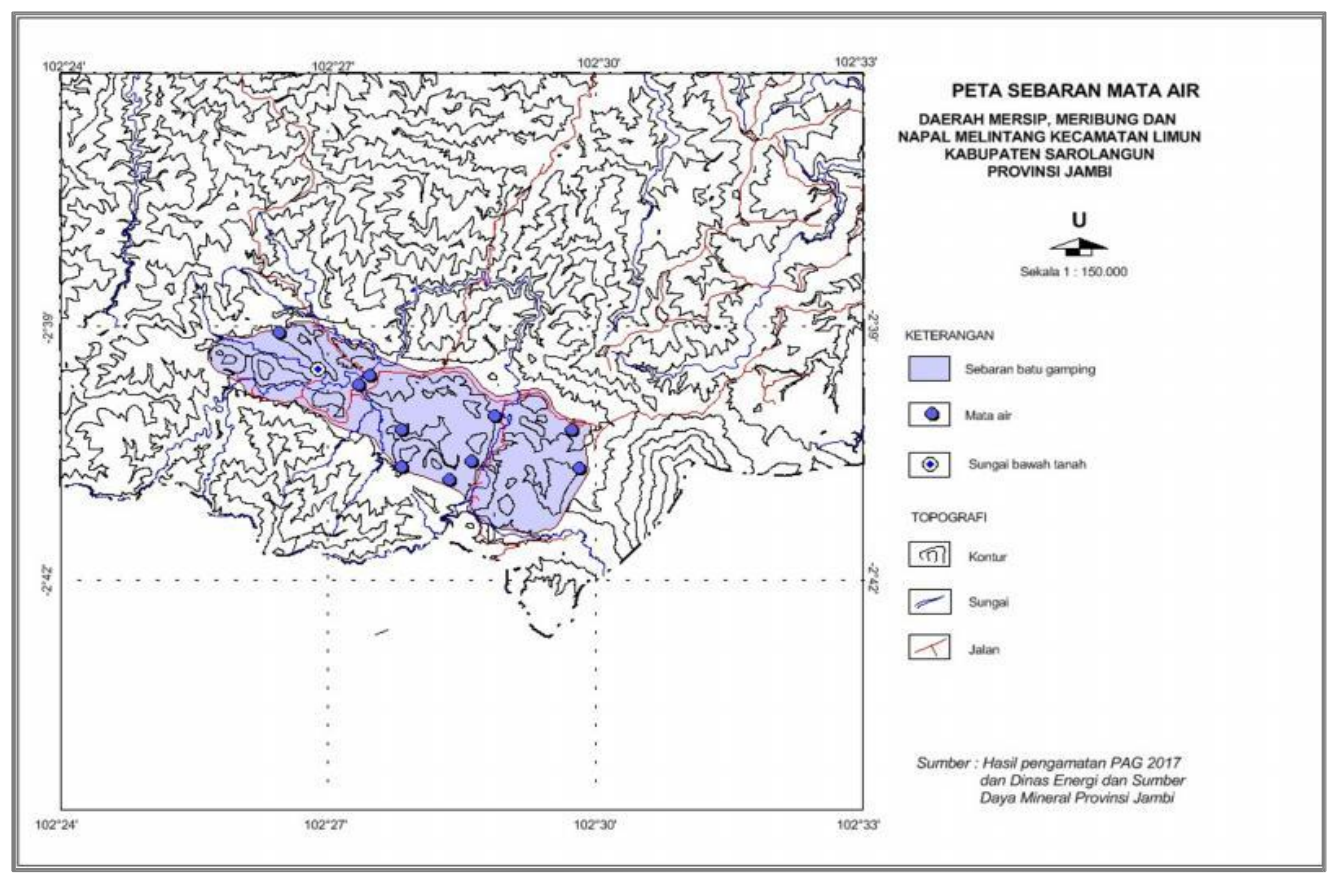

Gambar 7. Peta Sebaran Mataair Daerah Mersip dan sekitarnya

- Sebaran endokarst (gua dan sungai bawah tanah)

Secara umum gua yang teramati di pegunungan karst Mersip, Meribung dan Napal Melintang di Kecamatan Limun berupa gua horizontal berjarak pendek dan bersifat kering oleh penduduk setempat dinamakan gua kerbau, karena menjadi rumah bagi binatang kerbau. Indikasi adanya jaringan sungai bawah tanah adalah adanya sungai dengan aliran air yang deras berasal dari sungai bawah tanah biasanya terakumulasi pada cekungan yang kedap air menjadi telaga.

Keterdapatan gua karena pada umumnya tidak dijumpai hanya satu gua saja, tetapi merupakan sistem perguaan, antara satu gua dengan gua lainnya saling berhubungan. Hubungan antara gua di atas permukaan tanah maupun di bawah permukaan tanah, sebagian mempunyai hubungan dengan keberadaan sungai bawah tanah dan mata air.Sungai bawah tanah di daerah penyelidikan dijumpai di daerah Napal Melintang kondisi aliran air mengalir sepanjang tahun dengan fluktuasi penurunan debit air kecil debit air berkisar 14,5 $1 /$ det. Air tersebut digunakan oleh penduduk setempat untuk keperluan rumah tangga dan sebagainya.

- Berdasarkan hasil analisis dari data eksokarst dan endokarst yang terdapat di daerah Mersip, Meribung dan Napal Melintang, Kecamatan Limun, Kabupaten Sarolangun, Provinsi Jambi dapat disimpulkan bahwa pada beberapa lokasi menunjukkan eksokarst dan endokarst tertentu yang merupakan kriteria kawasan bentang alam karst (KAK) sesuai dengan Permen ESDM No. 17/2012 tentang penetapan KBAK. Eksokarst dan endokarst tertentu tersebut berupa mata air permanen, dolina dan gua basah. 


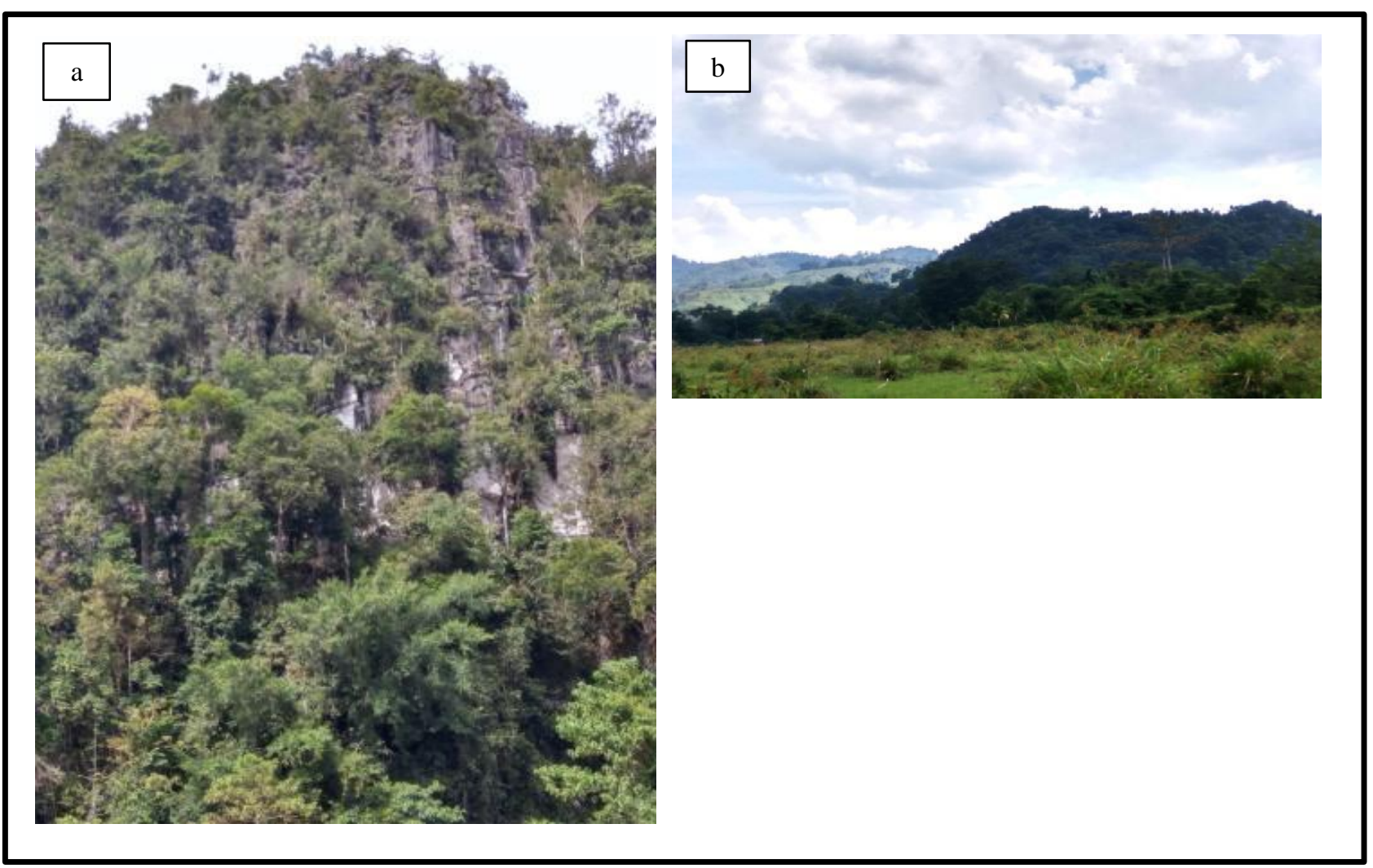

Sumber: dokumentasi PAG-GL 2017

Gambar 8. (a) Manifestasi eksokarst : Salah satu bukit karst dengan nama Bukit Bulan terletak di Desa Napal Melintang, (b) Lembah-lembah yang merupakan dolina di Desa Meribung yang dimanfaatkan sebagai lahan pertanian, dan (c) sebaran mataair di Kecamatan Limun, Kabupaten Sorolangun

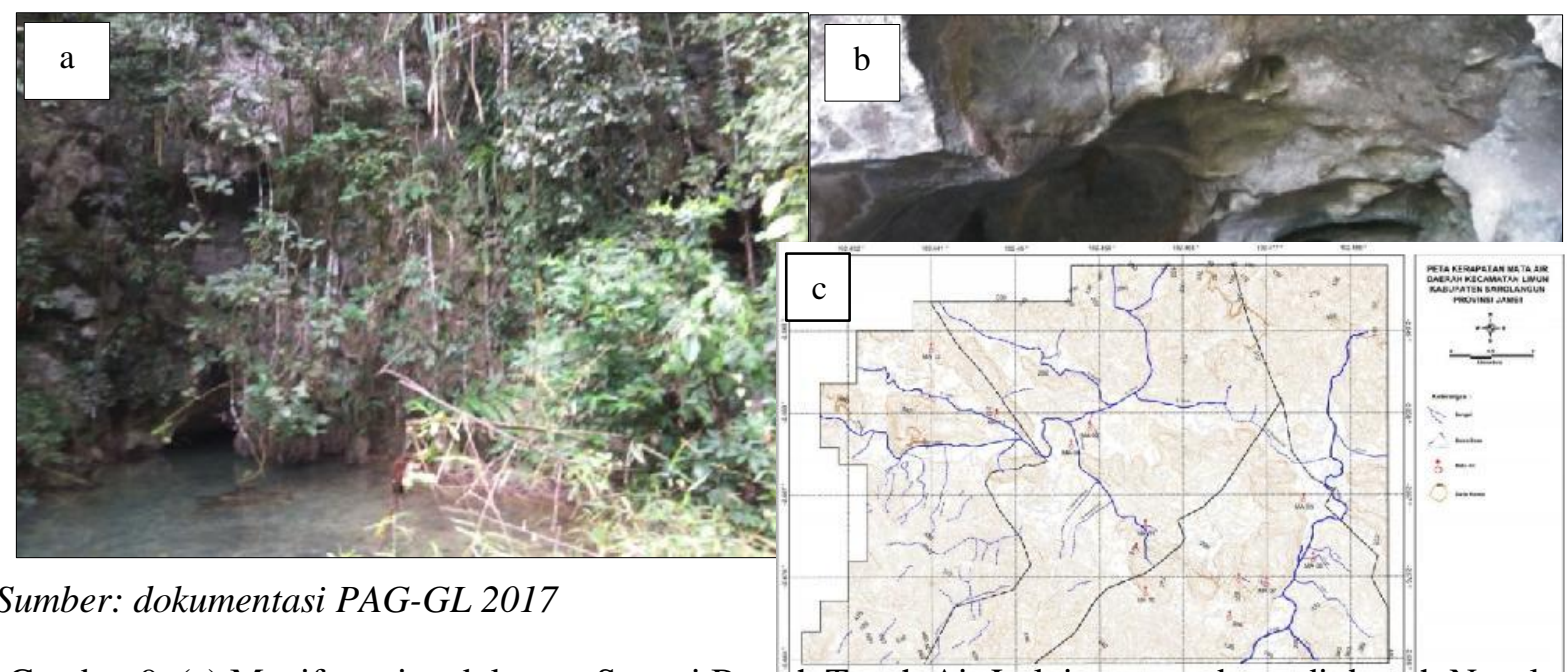

Gambar 9. (a) Manifestasi endokarst : Sungai Bawah Tanah Air Lului yang terdapat di daerah Napal Melintang, (b) Mulut gua Calo Petan Petak, merupakan gua yang mempunyai hubungan dengan keberadaan sungai bawah tanah dan mata air 
Berdasarkan kriteria yang termasuk eksokarst dan endokarst tersebut dideliniasi kawasan bentang alam karst yang diusulkan oleh Kabupaten Sarolangun untuk ditetapkan oleh Menteri ESDM. Peta usulan KBAK dari hasil kajian ini seperti terlihat pada Gambar 10

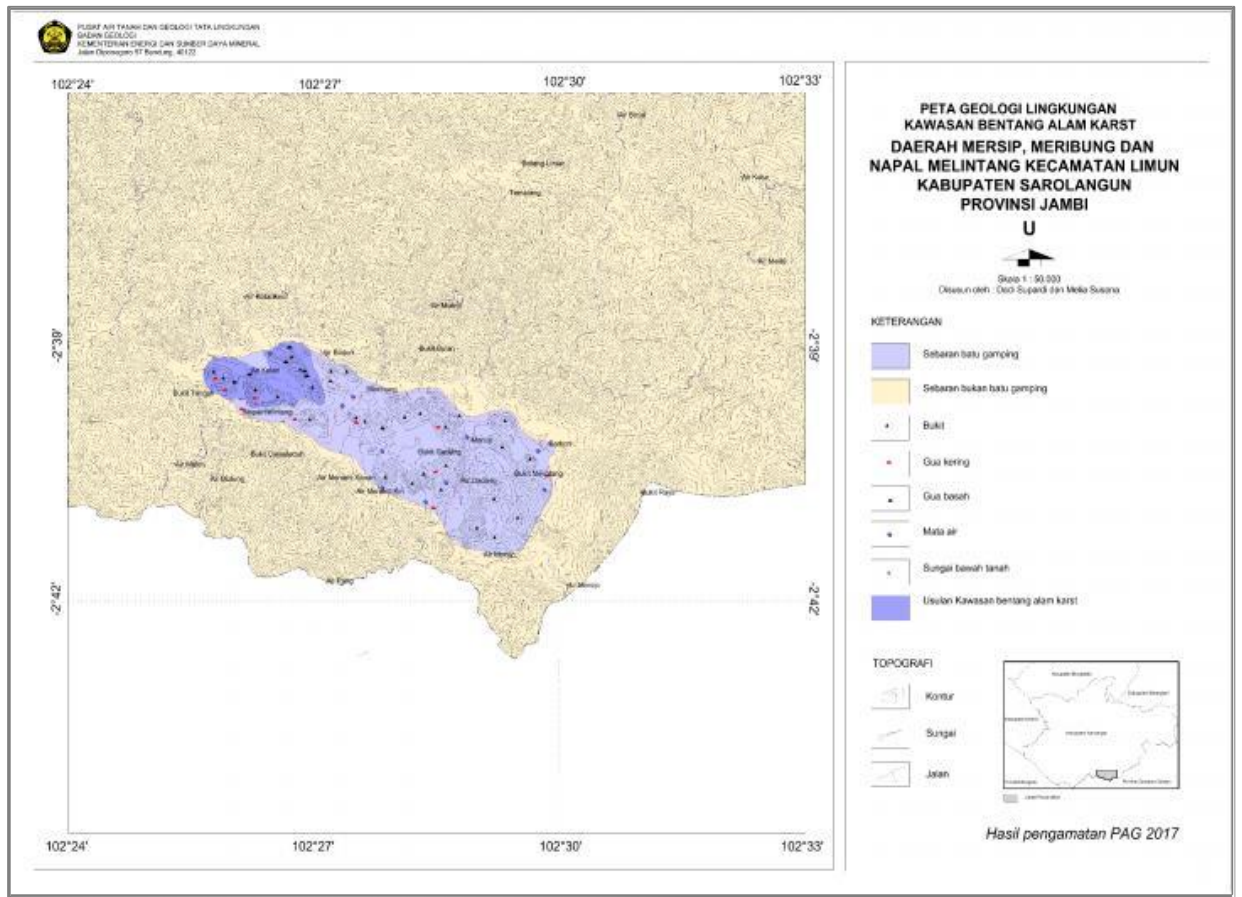

Gambar 10. Peta Usulan Penetapan KBAK Kabupaten Sorolangun, Provinsi Jambi

\section{D.4. Forum Group Diskusi Antar Pihak Terkait}

Tahapan akhir dari Penetapan Kawasan Bentang Alam Karst ini adalah sosialisasi ke masyarakat melalui forum group diskusi yang diadakan 3 (tiga) kali dengan mengundang semua stakeholder terkait, Tokoh masyarakat/agama, Lembaga Swadaya Masyarakat, WALHI, dan pihak industri khususnya perusahaan semen.

\section{D.5. Penetapan Menteri Energi dan Sumber Daya Mineral}

Hasil dari semua rangkaian diatas adalah Keputusan Menteri Energi dan Sumber Daya Mineral Nomor 1982 K/40/MEM/2018 tanggal 22 Oktober 2018 tentang Penetapan Kawasan Bentang Alam Karts Bukit Bulan Kabupaten Sorolangun, Provinsi Jambi

Kawasan Bentang Alam Karst yang sudah ditetapkan dalam KeputusanMenteri Energi dan Sumber Daya Mineral antara lain :

i. Sukolilo (Jawa Timur)

ii. Gunungsewu (DIY, Jawa Tengah, Jawa Timur)

iii. Gombong (Jawa Tengah)

iv. Pangkalan (Jawa Barat)

v. Langkat (Sumatera Utara)

vi. Citatah (Jawa Barat)

vii. Bukit Bulan (Jambi)

viii. Pangandaran (Jawa Barat)

ix. Kutai Timur (Kalimantan Timur 


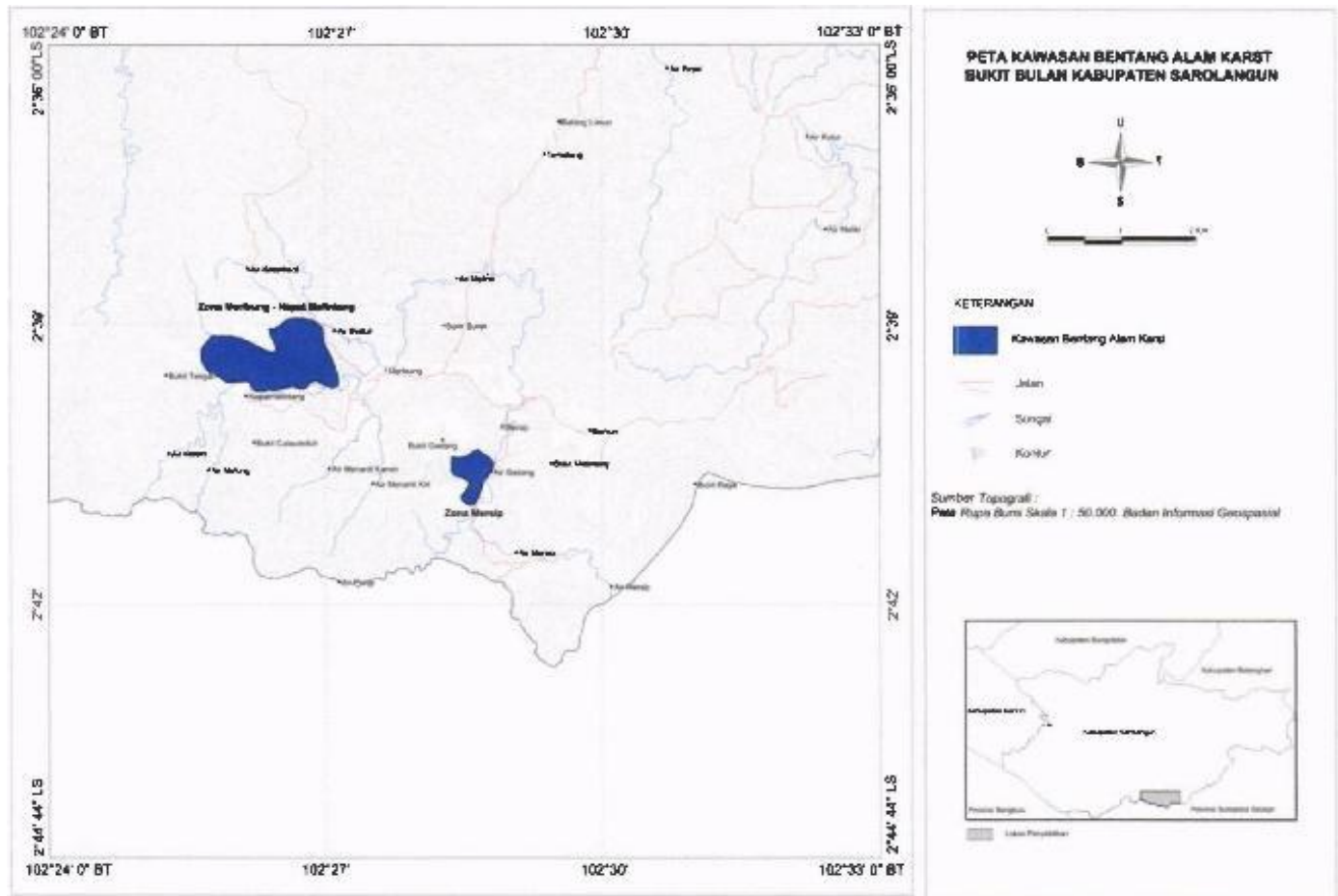

Gambar 11. Peta Kawasan Bentang Alam Karst Kabupaten Sorolangun, Provinsi Jambi

Tabel 1. Progress Penetapan KBAK per-1 Agustus 2019. (Peta lengkap Terlampir)

\begin{tabular}{|c|c|c|c|}
\hline NO & STATUS & JUMLAH DAN LOKASI & KETERANGAN \\
\hline 1 & $\begin{array}{l}\text { Yang sudah ditetapkan } \\
\text { menjadi KBAK }\end{array}$ & $\begin{array}{l}9 \text { KBAK (KBAK Sukolilo, } \\
\text { Gunungsewu,Gombong, } \\
\text { Pangkalan, Langkat, Citatah, Bukit } \\
\text { Bulan, Pangandaran, dan Kutai } \\
\text { Timur) }\end{array}$ & \\
\hline 2 & $\begin{array}{l}\text { Yang selesai dengan } \\
\text { Rekomendasi tidak } \\
\text { ditetapkan }\end{array}$ & $\begin{array}{l}7 \text { Lokasi (Manokwari, Cirebon, } \\
\text { Bolaang Mongondow, Pidie, } \\
\text { Kupang, Bolaang Mongondow } \\
\text { Timur, dan Cianjur) }\end{array}$ & \\
\hline 3 & $\begin{array}{l}\text { Yang sedang Percepatan } \\
\text { Penetapan }\end{array}$ & 2 Lokasi (sukabumi dan Bogor) & $\begin{array}{l}\text { Pembahasan internal } \\
\text { Badan Geologi }\end{array}$ \\
\hline 4 & $\begin{array}{l}\text { Yang terkendala kesepakatan } \\
\text { batas delineasi KBAK }\end{array}$ & $\begin{array}{l}4 \text { Lokasi (Lebak-Banten, Bogor- } \\
\text { Jawa Barat, Aceh Tamiang-Aceh } \\
\text { dan Tuban- Jawa Timur) }\end{array}$ & $\begin{array}{l}\text { Aceh Tamiang sudah } \\
\text { dilakukan evaluasi } \\
\text { usulan, namun masih } \\
\text { ada zona yang belum } \\
\text { dikaji }\end{array}$ \\
\hline 5 & Yang akan dikaji ulang & 2 Lokasi (Tasikmalaya dan Ciamis) & \\
\hline
\end{tabular}




\section{E. KESIMPULAN}

i. Sumberdaya geologi terdiri dari sumberdaya mineral, sumberdaya energi, sumberdaya air, dan bentang alam.

ii. Karst adalah bentang alam yang terbentuk akibat pelarutan air pada batugamping dan/atau dolomit. iii. Didalam Kawasan Bentang Alam Karst terdapat 2 (dua) sumber daya geologi, yaitu : sumber daya mineral $\left(\mathrm{CaCO}_{3}\right)$ dan sumber daya air. Bahkan dibeberapa tempat, bentang alamnya sangat indah sehingga layak dijadikan objek geowisata.

iii. Permen ESDM Nomor 17 Tahun 2012 adalah solusi untuk mengeksploitasi sumber daya mineral dan melindungi sumber daya air serta bentang alam. Hal ini dilakukan dengan melakukan deliniasi kawasan yang bisa ditambang dan kawasan yang harus dikonservasi.

iv. Kawasan yang tersusun dari batugamping yang tidak termasuk dalam kriteria Kawasan Bentang Alam Karst, baik yang sudah ditetapkan maupun yang akan ditetapkan oleh Menteri Energi dan

v. Sumber Daya Mineral dapat dimanfaatkan untuk keperluan industri, seperti : semen, cat, kapur tohor, pupuk, dan lain-lain.

vi. Tidak semua wilayah batugamping ditetapkan sebagai Kawasan Bentang Alam Karst, tergantung pada kondisi alam dan biasanya hanya sekitar 20-30\% dari sebaran batugamping di wilayah tersebut.

\section{UCAPAN TERIMA KASIH}

Artikel ini merupakan salah satu bentuk ekstraksi dari kegiatan Verifikasi Kawasan Bentang Alam Karst Kabupaten Sorolangun, Provinsi Jambi pada Bidang Geologi Lingkungan, Pusat Air Tanah dan Geologi Tata Lingkungan, Badan Geologi, Kementerian Energi dan Sumber Daya Mineral. Oleh karena itu, terima kasih tak terhingga dihaturkan kepada jajaran Pimpinan atas terlaksananya kegiatan tersebut. Serta Pemerintah Kabupaten Sorolangun dan masyarakat yang telah membantu tim pelaksana

\section{DAFTAR PUSTAKA}

Badan Pusat Statistik Kabupaten Sorolangun (2018) : Kabupaten Sorolangun Dalam Angka.

Cao, J., Hu, B., Groves, C., Huang, F., Yang, H., Zhang, C. (2016) : Karst dynamic system and the carbon cycle. Zeitschrift fur Geomorphologie, Vol. 60, Suppl. 2, 035-055.

De Coster, G.L., (1974) : The Geology of The Central and South Sumatera Basin, Proc. Indonesia Petroleum Association, 3rd Ann. Conv. ESDM, (2012) : Penetapan Kawasan Bentang Alam Karst, Peraturan Menteri ESDM No 17 Tahun 2012.

ESDM, (2000) : Pedoman Pengelolaan Kawasan Karst, Keputusan Menteri Energi dan Sumber Daya Mineral Nomor : $1456 \mathrm{k} / 20 / \mathrm{mem} / 2000$.

Irawan D.E \&Juanda D.P, (2013): Lembar Kerja Hidrogeologi Umum, Kelompok Keahlian Geologi Terapan, ITB.

Oktariadi.O\&Tarwedi.E,(2011) : Klasifikasi karst untuk kawasan lindung dan kawasan budidaya, Studi kasus Karst Bukit Bulan, Kabupaten Sarolangun, Provinsi Jambi, Jurnal Lingkungan dan Bencana Geologi, Vol 2 No 1, 1-19, Badan Geologi.

Peraturan Daerah Kabupaten Sorolangun Nomor 2 Tahun 2012 tentang Rencana Tata Ruang Wilayah Kabupaten Sorolangun Tahun 2011-2031.

Pulonggono, A., (1986) : Tertiary Structural Features Related to Extentional and Compressive Tectonics in The Palembang Basin, South Sumatera. Proc. Indonesia Petroleum Association, 15th Ann. Conv. Ruswanto, Rajiyowiryono.H, Darmawan.A, (2008) : Klasifikasi Kawasan 
Karst Sukolilo, Kabupaten Pati, Provinsi Jawa Tengah, Buletin Geologi Tata Lingkungan Vol 18 No 2.

Samodra, H. (2001) : Nilai Strategis Kawasan Karst Di Indonesia, Pengelolaan dan Perlindungannya, Pusat Penelitian dan Pengembangan Geologi Bandung.

Suwarna.N, Suharso, Gafoer.S, Amin.T.C, Kusnama, Hermanto.B, (1992): Peta Geologi Regional Lembar Sarolangun, Sumatera, skala $1: 250.000$, Pusat Penelitian dan Pengembangan Geologi. Van Bemmelen, RW.,(1949) : The Geology of Indonesia, vol. Ia, Martinus Nijhoff the Hague. 


\section{Lampiran Peta KBAK vang sudah ditetapkan oleh Menteri Energi dan Sumber Dava Mineral}

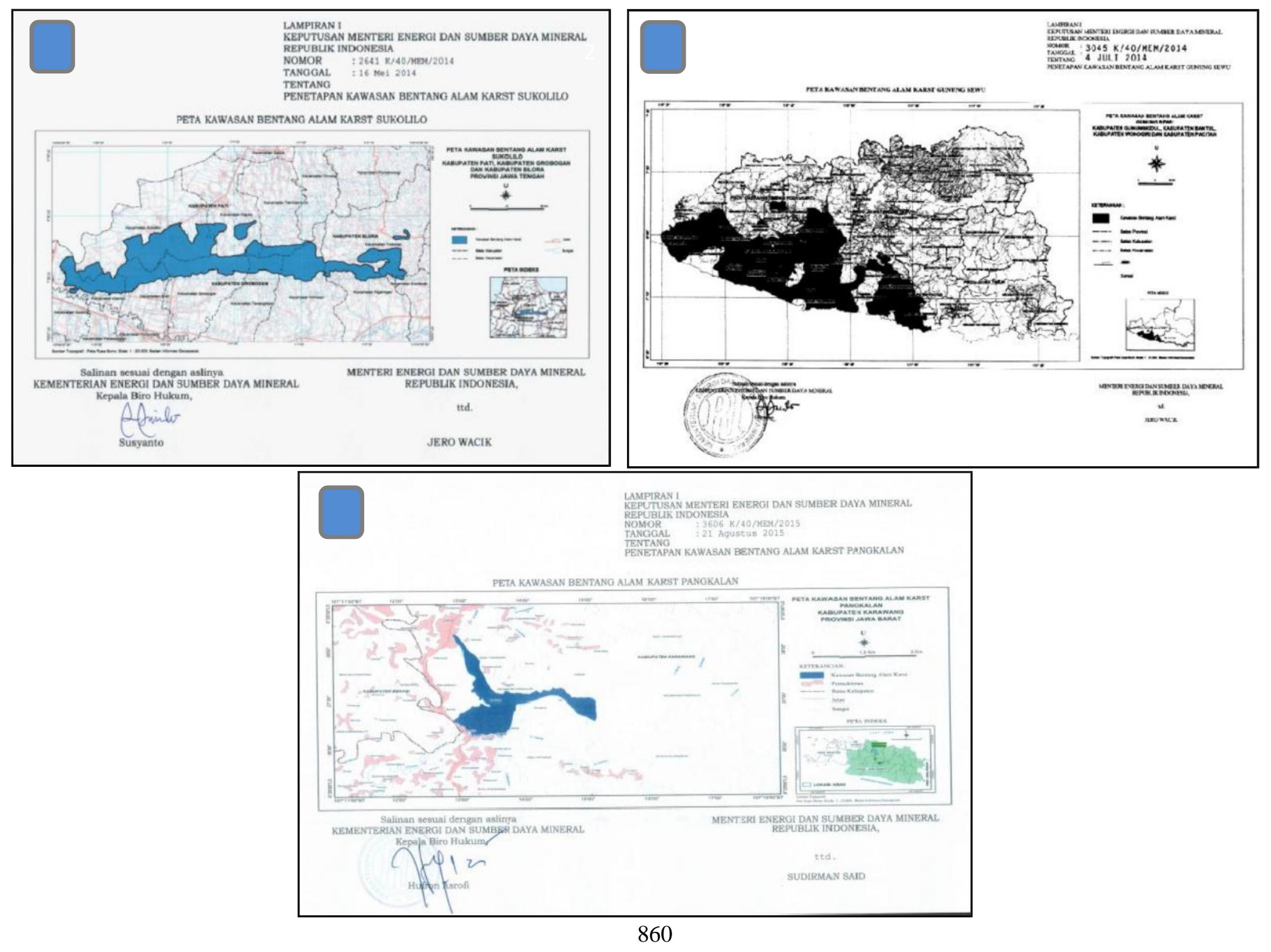



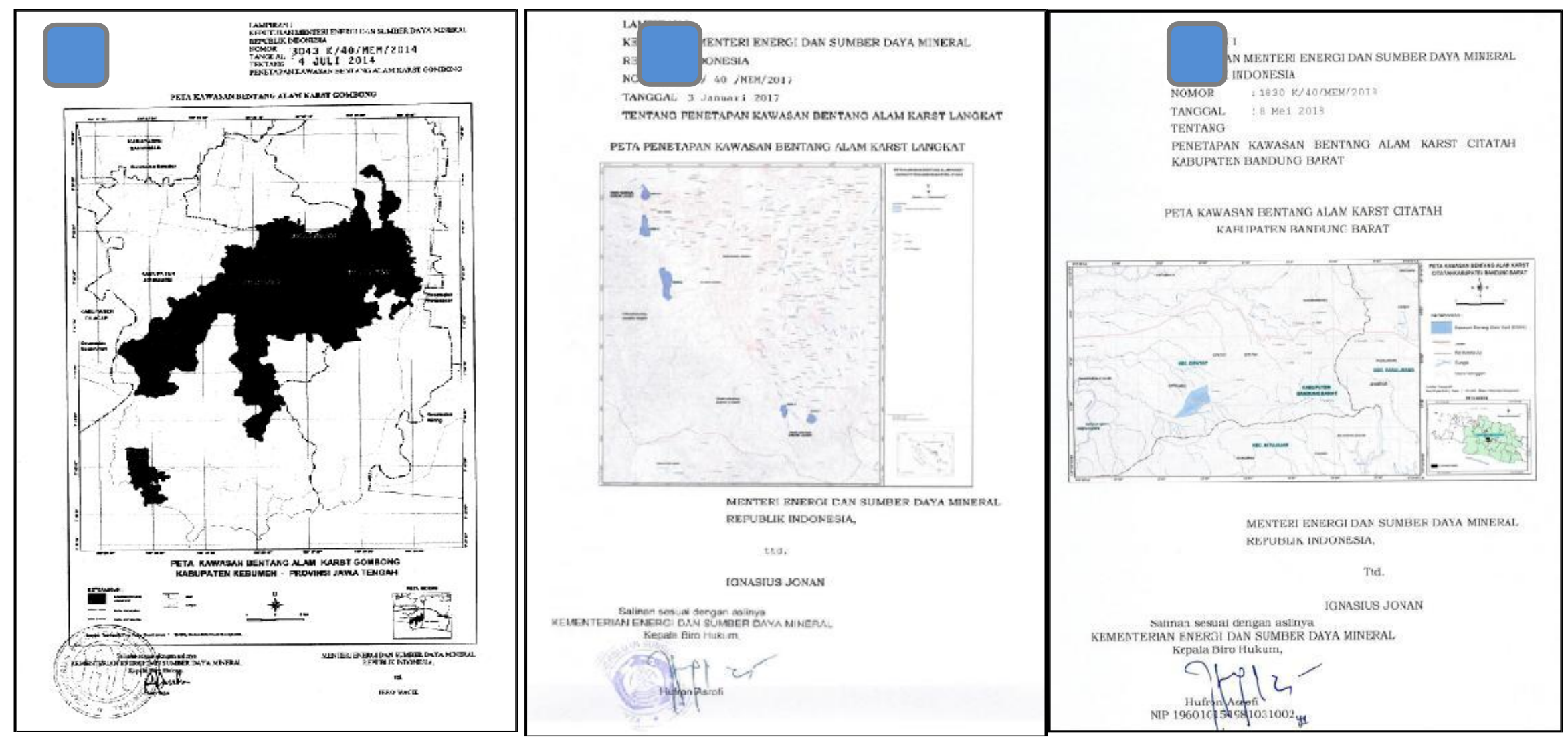


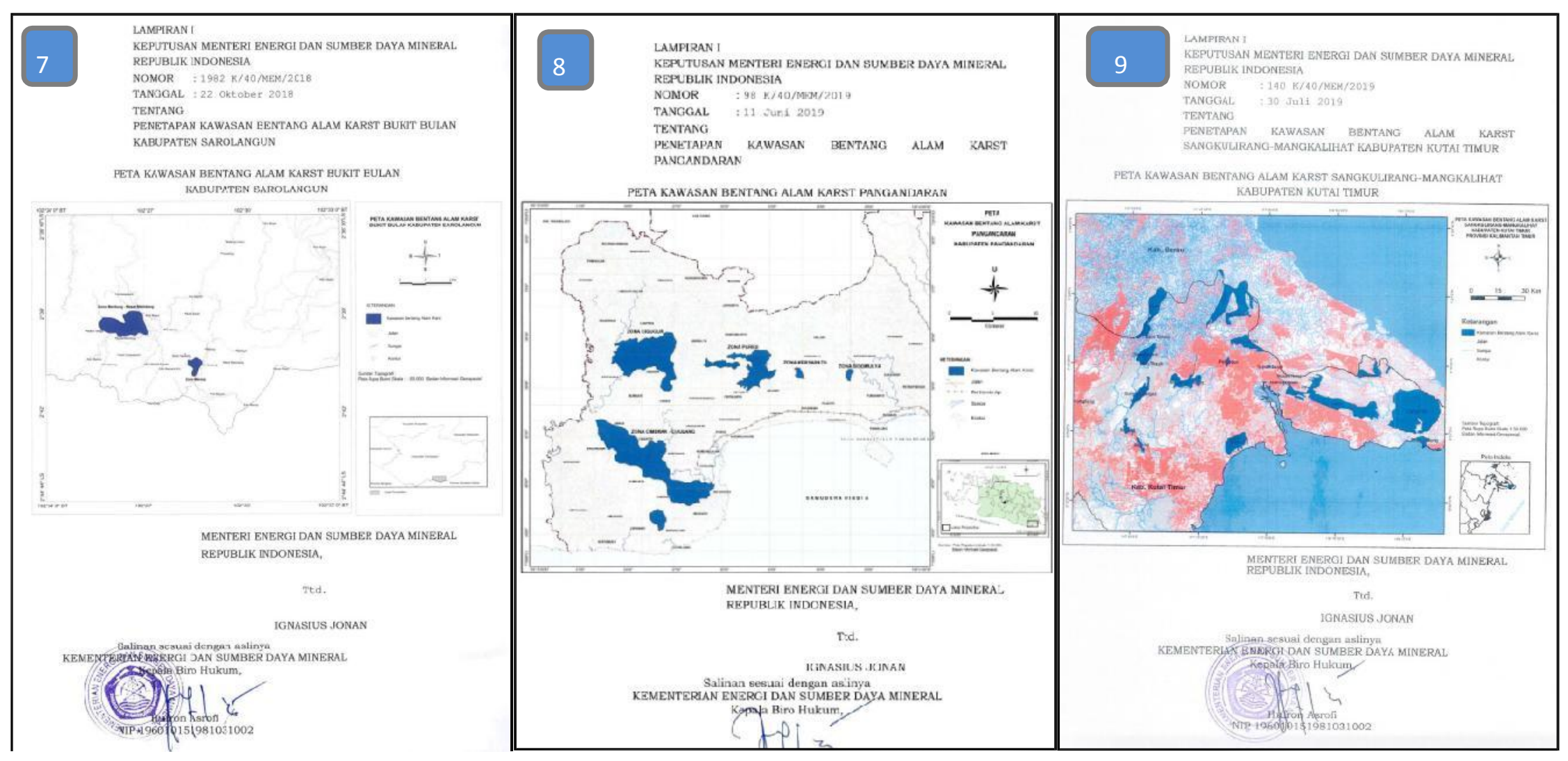

Keputusan Menteri ESDM tentang Penetapan Kawasan Bentang Alam Karst :
1. Sukolilo
2. Pangkalan
3. Gunungsewu
4. Gombong
5. Langkat
6. Citatah
7. Bukit Bulan
8. Pangandaran
9. Sangkurilang-Mangkaliat 